\title{
PENGARUH PENGAJARAN IMAN DAN PENDERITAAN MENURUT FILIPI 1:29 TERHADAP PERTUMBUHAN IMAN JEMAAT BETHANY KRISTUS SABDA BENJENG
}

\author{
Ani Teguh Purwanto \\ Sekolah Tinggi Teologi Injili Indonesia-Surabaya \\ E-mail: aniteguhpurwanto@sttii-surabaya.ac.id
}

\begin{abstract}
This study aims to examine the effect of the teaching of faith and suffering according to Philippians 1: 29 on the growth of the faith of the Bethany Christ of the Benjeng Word. The reason for this research is due to the low growth of the faith of the congregation due to the lack of understanding of the church about the teachings of faith and suffering. The sample of this research was 35 people from Bethany Christ, the Word of Benjeng Gresik, obtained through simple random sampling. The results showed that: 1). there is an influence between the teaching of faith and suffering with the growth of the faith of the church $(r=$ 0.487; $R$ square $=0.237 ; p=.000) ; 2$ ). the independent contribution of the teaching of faith and suffering to the dependent variablecongregational faith growth of $23.7 \%$. The implication of this research is that when the teaching of faith and suffering has a positive influence on the growth of the faith of the congregation, the congregation who receives good teachings of faith and suffering is expected to have good faith growth.
\end{abstract}

Keywords: Teaching of Faith, Suffering, Congregational faith growth

\begin{abstract}
Abstrak
Penelitian ini bertujuan untuk menguji pengaruh pengajaran iman dan penderitaan menurut Filipi 1 :29 terhadap pertumbuhan iman jemaat Bethany Kristus Sabda Benjeng. Alasan dari penelitian ini dikarenakan rendahnya pertumbuhan iman jemaat akibat dari kurangnya pemahaman jemaat akan pengajaran iman dan penderitaan. Sampel dari penelitian ini adalah jemaat Bethany Kristus Sabda Benjeng Gresik sebanyak 35 orang yang diperoleh melalui simple random sampling. Hasil penelitian menunjukkan bahwa : 1). ada pengaruh antara pengajaran iman dan penderitaan dengan pertumbuhan iman jemaat $(r=0.487 ; R$ square $=0.237 ; \mathrm{p}=.000) ; 2$ ). sumbangan independent variabel pengajaran iman dan penderitaan terhadap dependent variabel pertumbuhan iman jemaat sebesar $23,7 \%$. Implikasi dari penelitian ini adalah pada saat pengajaran iman dan penderitaan memiliki pengaruh positif terhadap pertumbuhan iman jemaat maka jemaat yang mendapatakan pengajaran iman dan penderitaan yang baik diharapkan akan memiliki pertumbuhan iman yang baik pula.
\end{abstract}

Kata Kunci: pengajaran iman, penderitaan, pertumbuhan iman jemaat 


\section{PENDAHULUAN}

Iman yang teguh/kuat akan terbentuk melalui proses yang disebut sebagai "penderitaan". Pada dasarnya setiap orang tidak mau mengalami penderitaan. Menjalani kehidupan ini kalau bisa lancar dan mulus tanpa ada masalah, persoalan yang menyebabkan penderitaan. Pemahaman akan pentingnya penderitaan yang memproses kehidupan orang percaya akan menjadikan iman semakin bertumbuh Menurut pendaapat Larry Crabb dalam bukunya yang berjudul "Perubahan Dari Dalam ke Luar" (1999) mengemukakan bahwa: "Pengalaman penderitaan memiliki kuasa untuk mengeraskan kita didalam sikap melindungi diri sendiri atau mengarahkan kita kepada kepercayaan yang lebih dalam lagi terhadap Tuhan.'Penderitaan orang Kristen mempunyai arti yang khusus. Karena penderitaan itu menyalibkan semua keinginan yang tidak berarti. Penderitaan begitu berlawanan dengan sikap kita, sehingga tidak semua orang bisa memahami penderitaan dengan sikap hati yang benar. Penderitaan membawa kita kepada suatu kesadaran akan status. Penderitaan akan menghasilkan kehidupan yang peka karena penderitaan merupakan pengajar yang terbaik untuk membentuk mental umat pilihan. Dengan demikian proses yang kita alami akan membentuk iman kita semakin teguh. Iman dan penderitaan adalah bagian terpenting dalam hidup orang percaya, karena itu adalah cara Allah mempersiapkan umat pilihan-Nya untuk menerima segala sesuatu yang dipercayakan kepada umat-Nya.

Pengalaman pertumbuhan iman jemaat yang satu dengan lainnya berbeda, khususnya mereka yang baru percaya. Yang masih memiliki pengertian yang dangkal tentang kekristenan, beranggapan kalau menjadi orang Kristen persoalanpersoalannya akan diselesaikan dan mendapatkan berkat-berkat materi. Mereka membutuhkan bimbingan dan pengajaran
Firman Tuhan secara mendalam. Seperti yang terjadi pada jemaat mula-mula, adalah bertekun dalam pengajaran rasul-rasul dan dalam persekutuan (Kis. 2:42). Dengan demikian kehidupan jemaat mula-mula mengalami pertumbuhan dan perkembangan yang pesat. Iman mereka bertumbuh semakin kuat. Orang percaya yang melewati proses masalah dan penderitaan dapat terbentuk karakternya untuk memiliki iman yang murni. Dengan demikian dapat memberi dampak pendewasaan iman bukan hanya BKSC (Gereja Bethany Kristus Sabda), tetapi juga bagi orang-orang percaya atau Kristen pada umumnya.

\section{METODOLOGI PENELITIAN}

Penelitian ini menggunakan metode kuantitatif yang bersifat korelasional, karena penelitian ini bertujuan untuk melihat pengaruh antara independen variabel (pengajaran iman dan penderitaan) dengan dependent variabel (pertumbuhan iman jemaat). Sesuai dengan tujuan penelitian, populasi dalam penelitian ini adalah seluruh jemaat Bethany Kristus Sabda Benjeng Gresik. Pengambilan sampel dilakukan dengan metode simple random sampling. Dikatakan simple atau sederhana karena pengambilan anggota sampel dari populasi dilakukan secara acak tanpa memperhatikan strata yang ada dalam populasi tersebut. Terpilih 35 jemaat sebagai sampel dalam penelitian ini.

Pengumpulan data penelitian dengan menggunakan skala Likert dan angket terbuka. Skala yang digunakan untuk mengukur pengajaran iman dan penderitaan dan pertumbuhan iman jemat berisi pertanyaan-pertanyaan terstruktur yang memberika kebebasan kepada responden untuk memilih jawaban yang tersedia. Angket terbuka digunakan untuk memperoleh data demografi subjek serta 
data yang diperlukan untuk melengkapi skala yang ada.

Penelitian ini dilaksanakan di Gereja Bethany Kristus Sabda (GBKS), desa Brangkal, kecamatan Balong Panggang, Gresik, yang dilaksanakan pada bulan Februari 2016 sampai dengan Agustus 2016.

Teknik analisis yang dipakai dalam menguji hipotesis ini adalah dengan menggunakan Pearson Product Moment Correlation untuk melihat pengaruh antara pengajaran iman dan penderitaan dengan pertumbuhan iman jemaat. Sebelum dilakukan uji hipotesis, terlebih dahulu dilakukan uji asumsi yang meliputi uji normalitas dan uji linieritas. Syarat sebaran data dikatakan terdistribusi secara normal jika $\mathrm{p}>0.01$, sedangkan syarat hubungan antar variabel fungsinya linier jika $\mathrm{p}<0,01$.

\section{HASIL DAN PEMBAHASAN}

Tabel 1.1 Identitas Subjek berdasarkan Jenis Kelamin

\begin{tabular}{lcc}
\hline Jenis Kelamin & Frekuensi & Persentase \\
\hline Laki-laki & 14 & 40 \\
\hline Perempuan & 21 & 60 \\
\hline Total & 35 & 100 \\
\hline
\end{tabular}

Dari tabel 1.1 diketahui bahwa $60 \%$ subjek berjenis kelamin perempuan dan $40 \%$ subjek berjenis kelamin laki-laki.

\section{Tabel 1.2 Identitas Subjek berdasarkan Usia}

\begin{tabular}{ccc}
\hline $\begin{array}{c}\text { Usia } \\
\text { Responden }\end{array}$ & Frekuensi & Persentase \\
\hline $\mathbf{2 0 - 3 0}$ th & 11 & 31.4 \\
\hline $\mathbf{3 1 - 4 0}$ th & 6 & 17.1 \\
\hline $\mathbf{4 1 - 5 0}$ th & 13 & 37.1 \\
\hline $\mathbf{5 1 - 6 0}$ th & 5 & 14.3 \\
\hline Total & 35 & 100 \\
\hline
\end{tabular}

Dari tabel 1.2 diketahui bahwa $37 \%$ subjek berusia 41 - 50 tahun, dan $31,4 \%$ subjek berusia 20 - 30 tahun.

Tabel 1.3 Identitas Subjek berdasarkan Tingkat Pendidikan

\begin{tabular}{lcc}
\hline Pendidikan & Frekuensi & Persentase \\
\hline S-1 & 13 & 37.1 \\
\hline SMA & 2 & 5.7 \\
\hline SMP & 17 & 48.6 \\
\hline SD & 3 & 8.6 \\
\hline & 35 & 100
\end{tabular}

Dari tabel 1.3 terlihat ada 13 orang atau $37,1 \%$ responden yang menempuh pendidikan Sekolah Dasar, kemudian ada 2 orang atau $5,7 \%$ yang menempuh pendidikan SMP, ada 17 orang atau 48,6\% yang menempuh pendidikan SMA atau SMK, dan 3 orang atau $8,6 \%$ yang menempuh pendidikan Sarjana.

Tabel 1.4 Identitas Subjek berdasarkan Jenis Pekerjaan

\begin{tabular}{ccc}
\hline $\begin{array}{c}\text { Pekerjaan } \\
\text { Responden }\end{array}$ & Frekuensi & Persentase \\
\hline Petani & 6 & 17.1 \\
\hline Wiraswasta & 16 & 45.7 \\
\hline PNS & 1 & 2.9 \\
\hline $\begin{array}{c}\text { Pekerjaan } \\
\text { lain-lain }\end{array}$ & 12 & 34.3 \\
\hline Total & 35 & 100 \\
\hline
\end{tabular}

Dari tabel 1.4 diketahui bahwa $45.7 \%$ subjek bekerja wiraswasta, dan $34,3 \%$ subjek bekerja lain-lain.

Tabel 1.5 Identitas Subjek berdasarkan Keterlibatn dalam Pelayanan

\begin{tabular}{ccc}
\hline $\begin{array}{c}\text { Keterlibatan } \\
\text { Pelayanan }\end{array}$ & Frekuensi & Persentase \\
\hline $\begin{array}{c}\text { penerima } \\
\text { tamu }\end{array}$ & 4 & 11.4 \\
\hline kolektan & 4 & 11.4 \\
\hline singers & 5 & 14.3 \\
\hline WL & 4 & 11.4 \\
\hline pemain musik & 5 & 14.3 \\
\hline
\end{tabular}


Jurnal Teologi \& Pelayanan ( Kerusso )

E-ISSN: 2714-9587

P-ISSN: 2407-554X

\begin{tabular}{rcccc}
\hline $\begin{array}{r}\text { pendoa } \\
\text { syafaat }\end{array}$ & 1 & 2.9 & & $\begin{array}{l}\text { demikian ada pengaruh pengajaran iman } \\
\text { dan penderitaan terhadap pertumbuhan }\end{array}$ \\
iman jemaat.
\end{tabular}

\section{PEMBAHASAN}

Dari tabel 1.5 terlihat ada 4 subjek atau $11,4 \%$ subjek yang terlibat sebagai penerima tamu, kolektan dan Worship Leader, 5 subjek atau 14,3\% subjek yang terlibat sebagai pemain musik dan singer, 1 subjek sebagai pendoa syafaat dan 12 subjek atau $34,3 \%$ subjek hanya terlibat sebagai jemaat biasa.

\section{PENGARUH PENGAJARAN IMAN DAN PENDERITAAN TERHADAP PERTUMBUHAN IMAN JEMAAT}

Uji asumsi normalitas dilakukan terlebih dahulu sebelum uji hipotesis. Hasil pengujian data pertumbuhan iman jemaat memiliki sebaran normal karena karena nilai $p$ Kolmogorov-Smirnov $0.869>0.05$. Sebaran datanya berdistribusi normal sehingga uji hipotesis dapat dilakukan dengan uji parametrik untuk variabel $Y$ Pengaruh pengajaran iman dan penderitaan terhadap pertumbuhan iman jemaat diuji dengan menggunakan regresi linier. Hasil uji pengaruh pengajaran iman dan penderitaan terhadap pertumbuhan iman jemaat terdapat pada Tabel 1.6.

\section{Tabel 1.6 Hasil Uji Hipotesis}

\begin{tabular}{|c|c|c|c|c|}
\hline $\begin{array}{l}\text { Pengaruh } \\
\text { Variabel }\end{array}$ & $\mathrm{R}$ & $\mathrm{R}^{2}$ & $\mathrm{P}$ & Keterangan \\
\hline $\begin{array}{l}\text { Pengajara } \\
\mathrm{n} \text { iman } \\
\text { dan } \\
\text { penderitaa } \\
\mathrm{n} \text { terhadap } \\
\text { pertumbuh } \\
\text { an iman } \\
\text { jemaat }\end{array}$ & $\begin{array}{l}0.48 \\
7\end{array}$ & $\begin{array}{l}0.2 \\
37\end{array}$ & $\begin{array}{l}0.00 \\
0\end{array}$ & $\begin{array}{l}\text { Ada } \\
\text { pengaruh }\end{array}$ \\
\hline
\end{tabular}

Hasil uji hipotesis dengan menggunakan regresi linier didapatkan nilai $\mathrm{R}=0.487, \mathrm{R}^{2}=0.237$ dan $\mathrm{p}=0.000(<$ 0.05), sehingga Ho ditolak. Dengan

Secara teologis makna pengajaran penderitaan dan iman menurut Filipi 1:29 bahwa iman dan penderitaan adalah satu paket anugerah/kasih karunia dari Allah. Pada saat seseorang memperoleh karunia untuk menjadi percaya maka manusia pun dikaruniakan penderitaan yakni menderita karena Kristus. Penderitaan dikaruniakan untuk menghasilkan iman yang murni. Iman bukan hanya suatu bentuk pengakuan tentang Kristus, tetapi juga suatu tindakan yang terbit dari hati orang percaya sebagai pengikut Kristus. Dalam hal ini bukan merupakan tindakan sesaat, tetapi tindakan dan sikap yang berkesinambungan yang harus bertumbuh dan dikuatkan secara terus menerus, hari lepas hari. Allah tidak hanya memberikan hal-hal yang menyenangkan tetapi juga hal-hal yang tidak menyenangkan seperti penderitaan, karena pada akhirnya adalah untuk kebaikan manusia itu sendiri. Lukas 9:23 mengatakan bahwa "Setiap orang yang mau mengikut Aku ia harus menyangkal diri dan memikul salib". Pengajaran yang benar akan memengaruhi orang percaya, sebab setiap orang percaya pada Kristus perlu untuk mengetahui dengan pasti dimana orang itu membangun dasar hidupnya.

Salah satu penyebab orang percaya pada Kristus tidak hidup oleh iman adalah karena orang itu tidak tahu dengan pasti kepada siapa orang itu percaya. Orang percaya pada Kristus tidak mudah diperdaya oleh berbagai ajaran sesat dan berbagai situasi yang menyulitkan hidupnya, orang itu harus memiliki dasar iman yang teguh, sehingga pada akhirnya orang itu dapat memperoleh janji-janji Allah yang tergenapi dalam hidupnya.

Pertumbuhan iman seseorang akan memiliki ciri-ciri yang menunjukkan kedewasaan imannya. Adanya perubahan- 
perubahan dalam hidupnya sebagai ciptaan yang baru, seperti tertulis dalam 2 Korintus 5:17: "Jadi siapa yang ada di dalam Kristus. ia adalah ciptaan baru; yang lama sudah berlalu, sesungguhnya yang baru sudah datang." Sebagai ciptaan yang baru, dalam kehidupannya harus mengalami pertumbuhan rohani yang sehat.Firman Allah juga dinyatakan sebagai Dasar Iman. Paulus dalam suratnya kepada jemaat di Roma menyatakan dengan jelas dan tegas bahwa Paulus mempunyaim keyakinan yang kokoh dalam Injil yang adalah Firman

Allah yang berisi kabar baik bagi semua orang. Melalui Injil Paulus mendengar dan menerima, sehingga timbul iman atau percaya bahwa Injil adalah Firman Allah yang dapat menyelamatkan setiap orang percaya, termasuk diri Paulus sendiri. Bahkan Paulus mengakui dengan iman yang teguh bahwa Injil nyata kebenaran Allah. Paulus sadar bahwa iman bukan datang dengan sendirinya, melainkan iman datang karena karunia Allah melalui mendengar Firman Kristus.

Firman Allah disebut dasar iman, karena dari Firman Allah-lah maka timbul iman percaya dalam hati seseorang. Firman Allah dipakai oleh Allah sebagai dasar iman, dan Firman itu tersedia bagi tiap-tiap orang (Bill J Wesley, 1992).Setiap orang percaya pada Kristus harus memberi pengakuan dan percaya kepada-Nya dengan iman yang tulus. Orang percaya atau Kristen harus menerima Yesus Kristus sebagai Tuhan dan Juruselamat secara pribadi dalam hidupnya, dan menjalin persekutuan yang intim dengan-Nya melalui doa. Berdoa dan Firman Allah adalah cara untuk meningkatkan iman. Jikalau seseorang rindu untuk mendapatkan iman yang lebih kuat, haruslah iman yang ada padanya ditingkatkan dengan jalan percaya yang sungguh-sungguh kepada Yesus Kristus dan Firman-Nya sebagai dasar utama imannya. Satu-satunya kebutuhan orang percaya adalah tetap hidup oleh iman, menjadi kuat dan teguh, tidak melepaskan apa yang telah diterima dan tidak menjauhkan diri dari Yesus. Apabila setiap orang Kristen benar-benar memiliki dasar iman, maka hidupnya tidak akan mudah digoyahkan oleh berbagai ajaran dan filsafat dunia yang menyesatkan dalam situasi dan kondisi apapun (Sunday Adelaya, 2008).

Setelah membangun dasar iman dalam Yesus Kristus, maka pengajaran tentang iman dan penderitaan harus dipahami dengan benar karena keduanya adalah anugerah yang Allah berikan dalam satu paket (tidak bisa memilih salah satu). Apabila seseorang menolak penderitaan karena Kristus, maka ia tidak memiliki iman yang benar. Anda tidak bisa menjadi orang Kristen yang kuat, kokoh, teguh, dewasa dan berbuah tanpa pengajaran yang kuat dan benar. Ajaran sangat penting. Tanpa pengajaran yang benar, anda tidak punya iman yang benar. Rantosari Siahaan (2010) dlam bukunya Berubah Untuk Berbuah mengatakan bahwa jika orang Kristen taat melakukan pengajaran yang benar sesuai Firman-Nya, orang tersebut akan memiliki iman yang sejati.

\section{KESIMPULAN DAN SARAN}

Berdasarkan permasalahan dan pembahasan tentang pengaruh pengajaran iman dan penderitaan terhadap pertumbuhan iman jemaat, dapat disimpulkan sebagai berikut:

1. Diterimanya hipotesis yaitu ada pengaruh pengajaran iman dan penderitaan terhadap pertumbuhan iman jemaat dengan nilai $\mathrm{r}=0.487$ dan $\mathrm{p}=$ 0.000. Semakin sering diberikannya pengajaran iman dan penderitaan maka semakin tinggi pula pertumbuhan iman jemaat.

2. Sumbangan efektif pengajaran iman dan penderitaan terhadap pertumbuhan iman jemaat sebesar $23.7 \%$. Sedangkan $76,3 \%$ pertumbuhan iman jemaat dipengaruhi oleh faktor-faktor yang lain 
Berdasarkan kesimpulan bahwa terdapat pengaruh pengajaran iman dan penderitaan terhadap pertumbuhan iman jemaat, maka bagi setiap keluarga Kristen diharapkan dapat memberikan waktu dan tenaga untuk mendapatkan pengajaran iman dan penderitaan agar jemaat bertumbuh dalam iman oleh pelayanan pengajaran dari gereja setempat.Bagi Gembala Sidang, Hamba Tuhan dan Majelis Gereja sebagai orangorang yang bertugas membawa gereja ke arah yang benar sesuai kehendak Allah, diharapkan otoritas gereja inilah yang bertugas untuk merancang programprogram praktis untuk diselenggarakan pengajaran iman dan penderitaan terhadap pertumbuhan iman jemaat, supaya jemaat mengalami pertumbuhan iman Jemaat Bethany Kristus Sabda Benjeng.

\section{DAFTAR PUSTAKA}

[1]. Adelaya, Sunday.Yesus Yang tak Kau Kenal. Yogyakarta: Andi Offset, 2008

[2]. Crabb, Larry. Perubahan Dari Dalam Keluar, Jakarta: Nafiri Gabriel, 1999.

[3]. Wesley Brill. Dasar Yang Teguh. Bandung: Yayasan Kalam Hidup, 1992.

[4]. Siahaan, Ranto Sari. Berubah Untuk Berbuah. Yogyakarta: Andi, 2010.

[5]. Guthrie, Donald dkk. Tafsiran Alkitab Masa Kini 3 (Matius-Wahyu). Jakarta: BPK Gunung Mulia, 1983.

[6]. Hagelberg, D. Tafsiran Surat Filipi. Yogyakarta: ANDI, 2008.

[7]. Harvey, John D. "The "With Christ" Motif In Paul's Thought," Journal Of

The Evangelical Theological Society 35/3 (September 1992):329-340.

[8]. Haubeck, B. F. Drewes Wilfrid, Heinrich von Siebenthal. Kunci Bahasa Yunani Perjanjian Baru Surat Roma
Hingga Kitab Wahyu. Jakarta: BPK

Gunung Mulia, 2010.

[9]. Hawthorne, Gerald F. Word Biblical Commentary. Texas: Word Books, Publisher, 1983.

[10]. Magnis-Suseno, Franz. Etika Dasar: Masalah-masalah Pokok Filsafat Moral. Yogyakarta: Kanisius, 1993.

[11]. Mounce, William D. Basic of Biblical Greek; Dasar-dasar Yunani Biblika. Malang: Literatur SAAT, 2011. 